\title{
Analysis of the Causes and the Consequences of Consecutive RMB Appreciation
}

\author{
Shuixiang Luo', Yue Zhang2, Meilin Hu${ }^{3}$, Yuhong $\mathrm{Li}^{4}$ \\ ${ }^{1}$ Finane Office, Jinggangshan University, Ji'an, China \\ ${ }^{2}$ Business School, Jinggangshan University, Ji'an, China \\ ${ }^{3}$ Jilin University of Finance and Economics, Changchun, China \\ ${ }^{4}$ College of Economy and Management, Anqing Normal University, Anqing, Chin \\ Email: "liyuhong0718@hotmail.com
}

Received 18 December 2013; revised 18 January 2014; accepted 25 January 2014

Copyright (C) 2014 by authors and Scientific Research Publishing Inc.

This work is licensed under the Creative Commons Attribution International License (CC BY).

http://creativecommons.org/licenses/by/4.0/

(c) (i) Open Access

\begin{abstract}
Since the reform and opening-up, China's foreign trade has obtained at breakneck speed, and in the international competition accumulated the massive trade surplus and foreign exchange reserves. That makes some western countries claim that the value of RMB was severely underestimated, which brought about unprecedented and consecutive appreciation pressure of RMB. The appreciation of RMB is highly related to the balance of the internal and external economics. This paper analyzes the background and the impact on Chinese economy of RMB appreciation, and then puts forward some recommendations or strategies accordingly.
\end{abstract}

\section{Keywords}

RMB Appreciation; Exchange Rate; Import and Export

\section{Introduction}

RMB appreciation is not a fresh topic, but it has always been a hot topic. After the US subprime mortgage crisis, RMB appreciation issue surfaced again in people's eyes and became the focus of discussion of the international communities. RMB appreciation will bring well-being of the people of China, but also ills. Maintaining the stability of RMB exchange rate to us dollars will not only be conducive to China's economic development, but also be conducive to world economy towards the development of achieving the Millennium Development Plan.

Since the reform and opening up, Renminbi structural changes occurred in Chinese export products, and the proportion of primary processed products of export products continue to decrease, and the proportion of

*Corresponding author. 
processed finished products gradually increase, and technological content of export products increases high, of which mechanical and electrical products and high-tech products are the mainly products. China currently has hundreds of industrial products ranking first in the world; our industrial development trend of transition from the "workshop" to "world factory" is very obvious. Consecutive expansion of current account surplus reflects that the value of RMB and foreign sales prices of commodities may be underestimated; a strong economy will definitely create stronger RMB.

Not always the appreciation of RMB exchange rate pressures comes from the appreciation pressure of domestic and international market. Few years ago, the world economy fell into a valley, such as US, Japan, and European countries experienced its own economic problems, trade protectionism in other countries are quietly rising in this context, and till now, the economic development presents weak there. In particular, under the pressure of domestic interest groups, governments try to make a big fuss by the RMB exchange rate. The main reason for the United States hoping the appreciation of RMB is that they were sure China's currency manipulation caused a serious problem of manufacturing unemployment in the United States (Feenstra, 1987). They believed that China, Japan, Korea, China Taiwan and other countries or regions deliberately manipulating currencies in order to obtain huge export competitiveness, especially there is a serious underestimation of the Chinese RMB (see Figure 1). For so long a time, RMB was always depreciative to US dollars, just a little appreciation between 1994-2005.

It is the phenomenon that the development of manufacturing industry in US shrank, enterprises went bankrupt, and posed a serious unemployment, thus the US government had to exert more pressures on the Chinese government to urge the RMB appreciation. Since the reform of exchange rate, and in fact, China Yuan hits new record high against USD, The Yuan rose 14 basis points to reach 6.11 per US dollar, the strongest since July 2005 (see Figure 2), when the country launched reforms of the exchange rate mechanism, according to the China Foreign Exchange Trading System.

RMB appreciation has both pros and cons, RMB appreciation will have some negative effects, of course, on our economic development in short term, for example, in short term, imports of equipment and raw materials

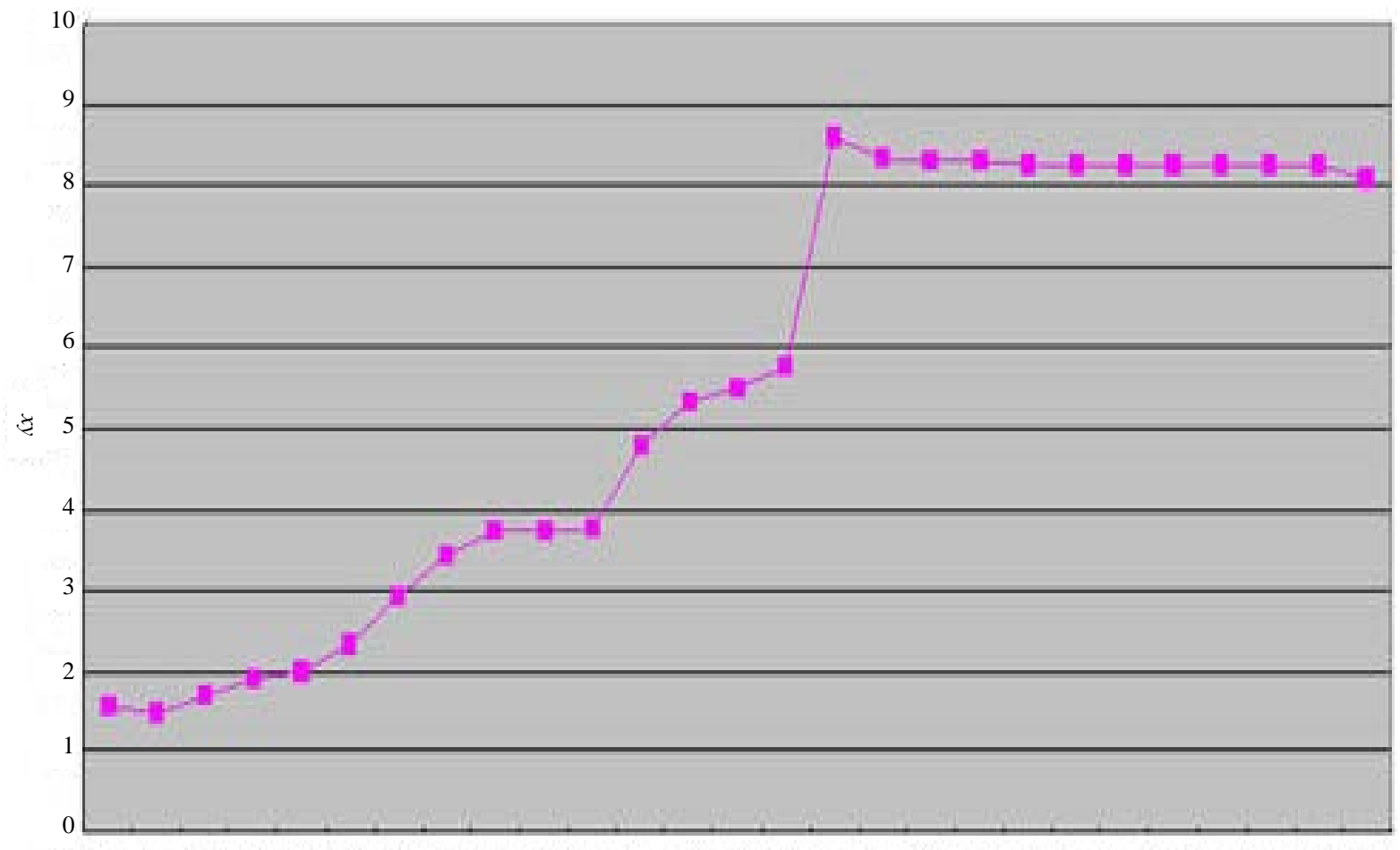

197919801981198219831984198519861987198819891990199119921993199419951996199719981999200020012002200320042005 
will increase, and trade deficit expands and so on. However, in the long run, RMB appreciation will be conducive to improving the economic efficiency of the export sector, to promoting structural adjustment, and to improving the export competitiveness, meanwhile, RMB appreciation can reduce the cost of imports, and promote domestic enterprises to import foreign advanced equipment and technologies and so on, which will contribute to upgrading the domestic enterprises of China, also improving the efficiency of domestic enterprises, and eventually reversing the trade surplus, thereby the country's trade balance would be improved. Brief Statistics on China's Import \& Export in October 2013 indicates that China’s import is sharply increasing and narrowing the trade deficit with foreign countries (see Table 1).

\section{Causes of Consecutive RMB Appreciation}

\subsection{International Environment Analysis}

China is a big agricultural country. The development of agriculture has the direct bearing on the success of building a well-being society, and narrows the gap between urban and rural areas. Agriculture negotiations can effectively correct the distortions existed in international agricultural markets and agricultural trade areas; strongly promote the restructuring and reform of global agricultural trade liberalization and European agricultural policy. From the view of prices trend and quality of our agricultural products, we can see that competition in the international market of agricultural products will shift from the previous high price subsidies to qualitycentric non-price competition. However, under the situation that international agricultural market prices generally decline, some agricultural prices in China rise because of the increment of their costs and managing circulation fee. In addition, China's agricultural exports are mostly primary products of poor quality, low-grade, less high added value, and the comparative advantage in the international market comes from their prices, while

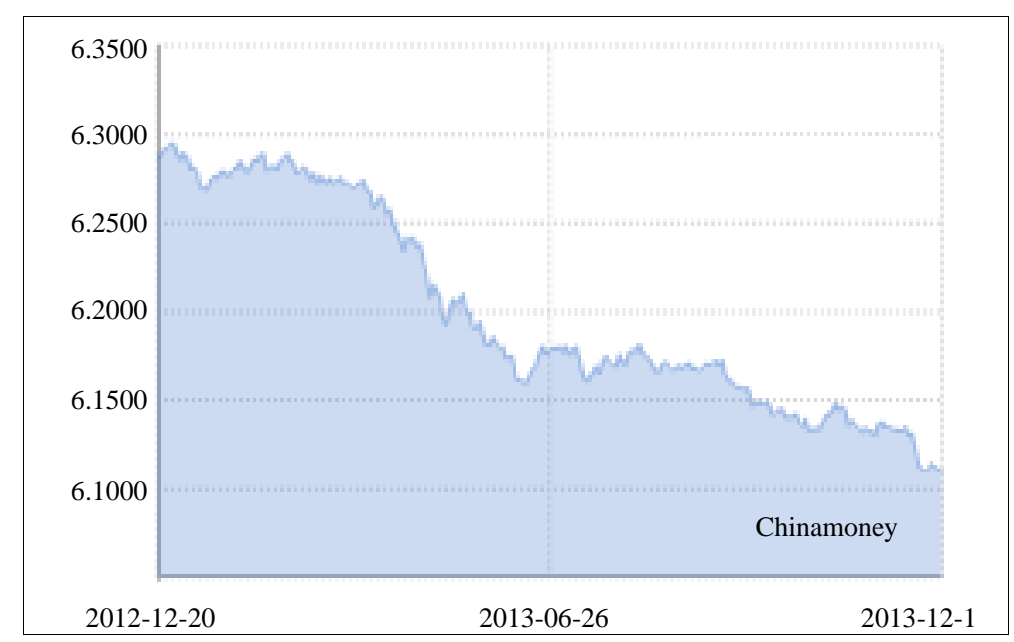

Figure 2. 2012-2013 RMB appreciation trend. Data: Ministry of Commerce People’s Republic of China.

Table 1. China’s import \& export in October 2013.

\begin{tabular}{|c|c|c|c|c|}
\hline & \multicolumn{2}{|c|}{ October } & \multicolumn{2}{|c|}{ January-October } \\
\hline & Absolute Value & Increase $\pm \%$ & Absolute Value & Increase $\pm \%$ \\
\hline Total Import and Export Value & 3397.0 & 6.5 & 33999.6 & 7.6 \\
\hline Export Value & 1854.1 & 5.6 & 18002.1 & 7.8 \\
\hline Import Value & 1543.0 & 7.6 & 15997.5 & 7.3 \\
\hline Import and Export Balance & 311.1 & -3.0 & 2004.6 & 11.5 \\
\hline
\end{tabular}

Data: Ministry of Commerce People’s Republic of China.

(http://english.mofcom.gov.cn/article/statistic/BriefStatistics/201311/20131100394504.shtml). 
the price advantage is based on cheaper labor, facing with high-quality and low-cost products from developed countries, competitive agricultural products in China will be eliminated by the international market sooner or later, if we don't increase the technological content timely. Therefore, both the US and the EU expressed their support on cutting tariffs of industrial products, they propose to cut the main export tariffs of seven areas in developing countries, and includes the current generally higher tariffs of clothing, shoes, textiles, leather products and so on, which is favorable to China owning cheaper labors. While it still needs negotiation and consultations so as to the friction on trade. Industrial tariffs Committee hopes the points raised can further promote members to unfold constructual discussions on this and enable the Commission on Market Access to agree on the modalities of tariff and non-tariff barriers. (Chow \& Yang, 2010) What's more, when discussing the content above, all members can comply with WTO agreements and publish their own point from the aspects of protecting multilateral trading system of WTO based on opening market, and encourage RMB appreciation.

\subsection{Mechanism Analysis on RMB Exchange Rate Reform}

For nearly 10 years, there have been several adjustments of the RMB exchange rate according to China's economy and foreign trade situation, but it remained basically stable and offered good premise for the continuance and steady growth of import and export. Since China entered into WTO in 2001, China's import and export's commodity had rapid growth in six consecutive years, annually average growth was about $28 \%$, which is much higher than the average annual growth rate of $17 \%$ since the reform and opening up. Economy and foreign trade of China developed sustainably and rapidly, sharp increment of surplus led to more and more pressure on RMB appreciation, and also brought about increasing difficulty on macro-economic regulation and control. The friction of foreign economy is also increasing day by day, some of the international blames for China's attack, technical barriers and anti-dumping became more and more frequent. In recent 10 years, China has been one who suffered more from anti-dumping complaints and investigations than any other country, and accounted for about one-third volume of complaints of WTO members, of which 28 cases of anti-dumping, countervailing 4 cases, 2 cases safeguards. In addition, 10 of the 337 investigations were from the US. Trade friction between China and United States, Japan, EU and other economies enter into the high-incidence season, US, EU, Japan and other countries or economies continuously made pressures on China, hoping to force RMB appreciation, the call for RMB appreciation is wave after wave internationally. Considering the need for sustained economic growth in China, and the basis of overall affordability, and on the premise of reasonable concessions to foreign partners asking for lower prices and benefit from development as a whole, People's Bank of China announced that since July 21st, 2005, China began to implement floating exchange rate regime based on market supply and demand, and adjust and manage with reference to a basket of currencies (including currencies of the United States, Japanese Yuan, Hong Kong dollars, European Union dollars, and other currencies of Indonesia, Malaysia, Singapore, Thailand, South Korea, Taiwan, Australia, Canada and other 12 countries or regions), and meanwhile, it announced a $2 \%$ appreciation of RMB, and it will float within a certain range. RMB appreciation is the flag of China who began to implement market-based supply and demand with reference to a basket of currencies, RMB exchange rate is no longer peg to the US dollar and form a more flexible RMB exchange rate mechanism, this is the reform measures taken for establishing and improving China's socialist market economy system, and giving full play to the basic role of the market in resource allocation. Comprehensive reform of the RMB exchange rate forming mechanism will profoundly impact on the future of China's import and export trade.

\section{Positive Consequences of RMB Appreciation}

\subsection{Imports Expand for Import Costs Decrease}

The improvement of trade conditions means that the same amount exported goods can exchange more imported goods. (Ma, 2007) Although China has a large trade surplus each year, due to prices constantly falling of export goods caused the continuous deterioration of trade conditions, and need to export a large amount of labor-intensive products in exchange for a small number of foreign high-tech products or scarce resources. After the appreciation of RMB, the price of exports relatively increase, so you can use less export products in exchange for a variety of products we need. Increasing export profits can improve our current terms of trade.

After the appreciation of RMB, prices of imported goods will fall down by the same scope for the transformation from foreign currencies to RMB, and the cost of imported goods and the fees paid at the import stage would 
decrease. According to the theory of demand elasticity, the bigger of the elasticity of demand for commodities, the greater of the imports adjustment will be for the change of import prices. The impact of RMB appreciation on different importing industries is different due to the differences of the price elasticity of different industries. Industries with higher import dependence of China mainly have oil and gas exploration industry, paper, iron and steel, petrochemical, aviation, transportation, electrical equipment and so on. RMB appreciation will reduce the import costs of large transactions, and further improve the profitability of related industries, which is a major positive consequence for our economic construction.

At present, China is in the stage of heavy industry development, many important strategic materials are demanded for economic development, such as oil, iron ore, copper and so on must rely on imports, the significant increase of Chinese demand has led to rapid increase of relative large commodity prices in international markets, and increase the costs of construction greatly. Modest appreciation of RMB is conducive to enhancing our purchasing power for raw materials, and mitigates the impact of rising oil and raw material prices on the economy. Enterprises being engaged in the import trade can get more profits consequently.

RMB appreciation will also reduce the prices of imported goods, and therefore will has impact on import substitution industries and the similar domestic products, especially those products that still have some distance with the advanced world products in terms of quality, brand, technology and so on, which will affect its market price and market share, and result in the deterioration of its profitability. Such industries include transportation equipment manufacturing, electronics and communications equipment manufacturing and so on.

\subsection{Currency Upgrades and Consumption Expands}

RMB appreciation means that costs of Chinese enterprises investing overseas will relatively decrease than before, and this will help the enterprises build multinational corporations abroad at a lower cost. Feng zhengqiang and Yang xiaoxia (2007). It allows them to make full use of global resources in accordance with the regional advantages of invested areas, and to reduce the production and transaction costs, then to achieve more scale economy, and establish a global production and marketing network. So it is conducive to Chinese companies to go aboard, namely, the faster RMB appreciates, the more truly competitiveness of multinational corporations of China will obtain. China's reform and opening up has entered a new phase, we will not only attract foreign investments, but also invest in foreign countries in the future. If RMB appreciates, then overseas direct investment costs of Chinese enterprises will decrease and it will be easier to develop overseas, and improve the quality in international competition areas. It will enable people in China to buy more goods from overseas, and improve the purchasing power of the people. Statistics indicates that more than two-thirds of luxury spending by Chinese mainlanders was made overseas in 2013, an increase from 2012, according to the China Luxury Market Study from consultant Bain \& Co released on December 17, 2013, and Chinese make up 29\% of luxury spending globally.

\subsection{Frictions Relieve and Development Sustains}

Years ago, China mainly implemented export-oriented strategy for long by quantitative expansion of cheaper labor-intensive products, and occupied the low-end market of the international labor-intensive industries with price advantage. Higher market share will inevitably increase trade conflicts between China and other trade countries. In recent years, China has been the one who suffers anti-dumping proceedings the most in the world. Hongjin Xiang, Zheng Zhan, Mingyong Lai (2011), appropriately to enhance the foreign currency prices of export products by RMB appreciation to relieve the anti-dumping pressure of foreign markets on our export products, meanwhile, it will also be conducive to improve the competitiveness of export enterprises through export support policies of cutting foreign exchange retention, export subsidies, trade credit and other aspects appropriately. It also allows our industries to grow rapidly abroad, to combine foreign advanced technologies and abundant labors to allow state-owned enterprises to participate in all over the world.

\subsection{Economic Structure Will Be Optimized and the Investments Are Improved}

The benefits brought about by industry structural adjustment and industrial up gradation presents in several aspects, it can greatly improve production efficiency and reduce production costs, and can improve product quality, and enhance the value of content of domestic products, and can produce products of higher technical require- 
ments, it can further help to expand the market space, and investors can make full use of global resources to enhance the commercial value of resources, and also it can help develop many alternative materials to reduce resource consumption and reduce environmental damages. Only upgrading industry, can we change our economic growth model and trade situation fundamentally. (Bei \& Zhu, 2008) Therefore, our future competitive advantage must go on the road of industrial upgrading, which is consistent with the requirements of the scientific development concept, and also meet the requirements of social and economic development. The proportion of traditional industries is relatively large in China's industrial structure, emerging industries is only in its infancy, it's an urgent need for future international competition to develop new industries, and strive to transform traditional industries to accelerate the upgrading of China's industrial structure. Industrial upgrading requires a lot of capital investment, especially foreign exchange capital investment.

Now, the RMB suffers appreciation pressure, and it should be a good opportunity, after RMB appreciation, the equipment of same dollar is much less converted into RMB, costs of introducing invested goods become relatively lower, it only needs to pay a relatively lower cost for the same patented technology, the same advanced equipment, which will greatly mobilize the enthusiasm of enterprises to introduce advanced equipment, purchase new technologies, and accelerate the pace of technology updates eventually, further speed up industrial restructuring and industrial upgrading, and improve the international competitiveness of domestic products. It can be definitely sure to make good use of the favorable opportunity of RMB appreciation to accelerate the renovation of traditional industries and accelerate the rapid development of new industries, and promote the upgrading of products, then our country will develop and occupy a new world in the international market.

\section{Negative Consequences of RMB Appreciation}

\subsection{Capital Outflows and Investment Shrinks}

RMB appreciation is definitely conducive to foreign enterprises that have already invested or have their own funds in China, for their assets appreciate with RMB appreciation, but it will make the upcoming entrepreneurs stagnating who will invest in China, because the cost of corresponding new investments rises. In addition, many of China's neighboring countries have provided very favorable investment conditions, so new funds may transfer to invest in other countries under the condition that there exists competition to attract investment in the surrounding areas, Wei Yang, Kit-Chun Joanna Lam (2012) which will lead to decrement of introducing and using foreign direct investment, and will also affect domestic employment rate and economic growth for capital out flowing. In addition, RMB appreciation will increase the export costs of enterprises that are processing trade-oriented enterprises, and then make foreign investment of proceeding trade decline. All of results will affect the scale of foreign-invested enterprises, the profits reinvested and the process of localized industries, and of course it will not be conducive to the sustainable development and upgrading of China's processing trade industries.

\subsection{More Imports Substitute for Exports}

RMB appreciation will increase foreign currency prices of export goods from China, and directly weaken the price competitiveness advantage of our exports. At present, we mainly export products of manufacturing industry which is easy to be alternative, this export of manufactured products mostly are low-tech products, not high-tech products. Xiaohui Liu, Conglai Fan (2010) once RMB appreciates, competitiveness of China’s manufacturing industries in the global markets may gradually disappear, and is prone to shift to overseas manufacturing. When RMB appreciates, foreign currency prices of unit exported goods from exporting companies will increase to maintain a certain profit, and it would be not conducive to continuous exports expanding and improving market share of products in the international market. Also, if we maintain the prices in international market, then it is bound to squeeze profit margins of export enterprises, thus, it will impact China's exports to a certain extent. Our cheaper goods cannot be sold out, and we will import large amount of foreign products, which will compete with domestic commodities, and definitely affect the development of our export industries.

\subsection{Industrial Disruption Leads to Employment Difficulties}

One of the important negative impacts of RMB appreciation is that it leads to disruption of the domestic industry and cause employment pressures. There are two main reasons: First, most of China's current export products are 
low-tech, labor-intensive products with low added-value, RMB appreciation weakens the export of labor-intensive products, and decrement of exports will inevitably increase the pressure on employment; second, it's export and foreign trade enterprises who offer new employment opportunities in China currently. RMB appreciation has a great influence on exports and foreign direct investment, thereby affected employment, and has some impact on the improvement of current employment environment. In addition, Mundell also cleared that RMB appreciation will accelerate China's deflation, and reduce economic growth, and increase unemployment pressure. Thus, RMB appreciation will further negatively influence on three objectives, including price stability, economic growth, and full employment. Therefore, the negative impact of RMB appreciation is very obvious on China's economy.

\subsection{Market Risks Increase for Price Fluctuation}

Consecutive RMB appreciation has attracted a large number of foreign short-term speculative capitals to penetrate to China, further hyping RMB exchange rate. This can easily lead to financial and monetary crisis under the condition that the development of China's financial market is far from healthy. In addition, the actual amount of the bank's existing non-performing assets will further rise because of RMB appreciation measured in US dollars, and is not conducive to reform and debt restructuring of the entire banking industries, the fluctuation of RMB exchange rates will seriously affect economic development, and also increase investment risk of enterprises in the long run.

\section{Recommendations}

1) Reinforce macro-control. Before the reform of RMB exchange rate, price of goods abroad is distorted due to the devaluation of RMB exchange rate, the price of exported goods is low, and the price of imported goods is high, resulting in expanding exports of our country in the past for a longer time, trade surplus increased gradually, large trade surplus occurs year after year persistently, causing trade frictions with trading partners frequently. Government departments should intensify macro-control policies, and carry out a variety of enterprise reforms, to actively cultivate and expand the domestic consumer market, to encourage investment, especially the private investment, and focus on supporting enterprises who own core competitiveness.

2) Expand domestic demand. In the past long period of time, due to the relatively undervalued RMB exchange rate leading to strong export growth, China's foreign trade continued to be in huge surplus. Many companies are trading in droves on the exports, resulting in capital, labor and other production factors flowing to export sector, community resources cannot achieve the optimal configuration based on market, resulting in the situation of insufficient domestic demand of China's economy, but over-reliance on exports is very unfavorable for our longterm stable and sustainable economic development. China has 1.3 billion people supporting a huge domestic consumption market, it can truly support the sustainable development of our economy, we must adjust the economic structure, reduce the dependence on foreign trade and exports, and achieve the change from exportoriented strategy to domestic demand-oriented strategy of sustainable economic development as soon as possible, a correct and scientific concept of development must be established right away. Meanwhile, the government should take effective measures to carry out various reforms, and actively cultivate and expand the domestic consumption market, and encourage investment, especially private investment, and focus more on supporting the core competitiveness of enterprises.

3) Encourage industrial upgrading. Industrial upgrading is an important measure of enterprises to deal with RMB appreciation currently. The key point of this approach is to develop new products based on the company's existing products, or carry out forward or backward elongation of the products, which can reduce intermediate profits links of the products, and give profits to the dealers of domestic and international market, until to consumers, thereby reducing the impact brought by RMB appreciation. This industrial upgrading is completely different with the converting approach of many domestic export-oriented SMEs (small and medium-size enterprises) currently, and industrial upgrading must belong to the industries with existing basis; enterprises can achieve development through the expansion of certain technologies, being very beneficial for the development of enterprises.

4) Encourage self-innovation of enterprises. Enterprises should enhance their competitiveness, and create their own brands, and implement their going-out strategy to deal with the challenges of RMB appreciation. Enterprises should take measures to strengthen technological innovation, manage innovation and brand innovation, 
and improve labor productivity and so on, and improve the competitiveness of the export enterprises fundamentally. In addition, companies should tap the internal potential, reduce production costs, and improve economic efficiency. To save unnecessary costs, the majority of export enterprises should grasp the internal management as start, fully tap the internal potential of enterprises to save energy and minimize procurement chain of raw material, to reduce procurement costs and improve productivity. In modern globalized world economy, Chinese enterprises are facing a competitive market with world brands. Exporting enterprises should improve the quality of export products as soon as possible, and enhance the product brand content as well as the design capabilities, and create brand advantage of export products, and take the high road of brand. Only in this way, can we avoid frequent anti-dumping investigation or safeguard measures from foreign countries to put pressure on companies of China.

5) Improve the exchange rate regime. Since 2005, China has begun to implement and will persist in floating exchange rate regime based on the market with reference to a basket of currencies. The new exchange rate mechanism will have an impact on economic growth and employment in the short term, but on the whole, it does more good than harms. We should actively and steadily push forward the reform of RMB exchange rate formation mechanism, to improve the market-oriented degree of exchange rate formation mechanism gradually, and make the exchange rate fluctuations of RMB more flexible, fluctuations in exchange rates could significantly reflect the changes in market supply and demand, and strengthen the coordination of the foreign currency policy, give full play to the role of exchange rates in the balance of payments to withstand shocks of international capital flows, and to meet the demands of opening up and development of market economy.

Above all, the RMB exchange rate reform should proceed from the demand side of the economy, considering trade and mutual economic interests among the trading partners and achieve a win-win situation.

\section{Acknowledgements}

This paper is financially supported by the projects Foreign Trade and Economic Development: Empirical Study on Southwest Minority Region of China (ID: JRB11046).

\section{References}

Bei, D. G., \& Zhu, X. L. (2008). A New Monetary Phenomenon: An Analysis of the Co-Existence of the External Appreciation and the Domestic Inflation of RMB. Frontiers of Economics in China, 6, 327-355. http://dx.doi.org/10.1007/s11459-008-0016-6

Chow, E. H., \& Yang, W. Y. (2010). Stock Return and Exchange Rate Risk: Evidence from Asian Stock Markets Based on a Bivariate GARCH Model. International Journal of Business, 2, 97-117

Feenstra, R. C. (1987). Symmetric Pass-Through of Tariffs and Exchange Rate under Inperfect Competition: An Empirical Test. NBER Working Paper.

Feng, Z. Q., \& Yang, X. X. (2007). Analysis of Impact of RMB Exchange Rate on China's Foreign Trade Structure. Economic Survey, 4, 42-44

Liu, X. H., \& Fan, C. L. (2010). The Model and Empirical Estimation of the Optimal Flexibility of RMB Exchange-Rate Regime: A Study Based on the Price-Stabilization. Frontiers of Economics in China, 5, 187-209. http://dx.doi.org/10.1007/s11459-010-0010-7

Ma, H. M. (2007). RMB Exchange Rate Is a New Opportunity for the Development of China's Foreign Trade. Economic Research Group, 8, 188-189.

Xiang, H. J., Zhan, Z., \& Lai, M. Y. (2011). The Trade Destruction Effect and Trade Diversion Effect of RMB Appreciation. Frontiers of Economics in China, 6, 479-493. http://dx.doi.org/10.1007/s11459-011-0143-3

Yang, W., \& Lam, K.-C. J. (2012). An Ethical Analysis of Economic Issues Related to the Appreciation of Renminbi. Asian Journal of Business Ethics, 1, 79-87. http://dx.doi.org/10.1007/s13520-011-0008-y 